\title{
Simulation Model Based Response Management Related to Railway (Earthquake) Disaster
}

\author{
Sergey Kinzhikeyev ${ }^{1}$, József Rohács ${ }^{1 *}$, Dániel Rohács ${ }^{1}$, Anita Boros ${ }^{2,3}$ \\ ${ }^{1}$ Department of Aeronautics, Naval Architecture and Railway Vehicles, Faculty of Transport Engineering and Vehicle Engineering, \\ Budapest University of Technology and Economics, Múegyetem rkp. 3, 1111 Budapest, Hungary \\ 2 Széchenyi István University, Globalization Competence Center, Egyetem tér 1, 9026 Győr, Hungary \\ ${ }^{3}$ Lajos Lőrinc Institute of Administrative Law, Faculty of Science of Public Governance and Administration, National University of Public \\ Service, Ludovika tér 2, 1083 Budapest, Hungary \\ * Corresponding author, e-mail: jrohacs@vrht.bme.hu
}

Received: 24 November 2020, Accepted: 15 June 2021, Published online: 13 September 2021

\begin{abstract}
Railway system as part of the general transportation system is a strategic element that supports the economy and the society. Its role is continuously rising with rapid industrialization, urbanization, and changes in the society expectations regarding sustainable systems. New and emerging technologies call and permit the augmentation of the railway systems' disaster management. This paper deals with the development of an improved response management concept related to railways' damage, caused by earthquakes. The paper synthetizes the latest technologies, engineering, and management methods in one improved response management system. After the concept inspiration, the paper describes the applicable novel models and introduces an improved response management being developed for railway systems, damaged by earthquakes. The concept is verified in simulation. The novelty includes a new approach in the identification of the critical infrastructure, the risk assessment, the prediction of aftershocks and the recursive application of the adaptive Markov process to the simulation supporting the response management concept.
\end{abstract}

Keywords

railway systems, earthquakes, emergency management, disaster response, response management methodology

\section{Introduction}

Railways play a deterministic role in the economy, society, and strategic defense duties. Such systems are called as large natural-technogenic system [1]. It is a man-made (-genic) technical/technological (techno) system based in the natural (ground-soil, water-rivers) environment. With a wider approach, such systems are ecological-socio-technogenic systems.

Railway systems are large, geographically distributed net of critical elements, critical infrastructures being composed of major tracks, bridges, tunnels, railway stations (as modal transportation centers), technical depos, (single) info-communication systems, energy supporting structures, monitoring, and warning elements, operation centers.

Railways as a strategic system must return to their operational level after a disaster as quickly as possible. Operational level means that railways are capable to transport people, goods, while the system's performance (as speed) might be limited. Therefore, the operational level depends on e.g., the initial infrastructure condition, damages, damages of the other transportation means. This is a performance that must be defined and maintained by the disaster response managers. (Track of high-speed rail must be fully repaired and tested before restarting the operation.)

Railway system must be developed, designed, and built for maximum loads caused by the earthquakes. Earthquakes generate a series of seismic waves that are generally followed by a sequence of aftershocks and secondary hazards (such as fire, volcanic actions, tsunamis, landslide, liquefaction) [2-6], change in ground level, and/or flooding and dam failure. Such disaster causes maximum loads in the railways system. Long-term prediction (about time, intensity, and location of future events) of earthquakes' occurrence is estimable by statistical and probabilistic models, while the short-term prediction today is rather problematic [7].

In general, aftershocks occur after the main earthquake with a relatively large probability [8] which can be predicted 
by several models $[9,10]$, However, these models cannot provide a general approximation due to the significant uncertainties related to the parameters, and the fact that the location of aftershock occurrences cannot be predicted robustly by the recent models. Secondary hazards play a significant role, causing around $30 \%$ of fatalities in earthquake disasters. These secondary effects can be observed easily and their evolution at areas with large population can be simulated and predicted with relatively good accuracy $[3,5]$.

The overall objective of this paper is to develop improved management rules for the technical response to earthquake damaged railway systems supported by a simulation model. This is a unique methodology that utilizes the available models, software [2-10], which should be applied to solve the problems caused by incomplete and randomly changed information in the framework of a set of management rules that applies the physics-based solutions, semi empirical, statistical/stochastic models and new approaches based on artificial intelligence.

The paper is composed of the following five major sections: (i) the concept inspiration, (ii) the description of the enhanced methods, rules (as the identification of the critical infrastructures, the development of a prediction technique related to aftershock appearance), (iii) the introduction of the improved response management methodology developed to earthquakes damaged railway systems, (iv) the concept verification with simulations and (v) the discussion of the results.

The novelty includes new approaches to identify the critical infrastructure, to perform risk assessment, to predict the aftershocks and to apply the adaptive Markov process over the simulations that support the response management.

\section{Concept inspiration}

An extensive investigation was performed, [11,12] on:

- the role of railways in the modern economy, society, and mobility,

- the historical data of earthquake disaster events and their damages caused in the railway systems,

- the legal control system developed for disaster management,

- the possible and applicable methods,

- the new available and emerging technologies, solutions, methods, rules, software,

- the possible synthesis of the engineering methods and management art (methods).

The most important results of these investigations are summarized in the follow-up sections.

\subsection{Statistical data available}

Large sets of statistical data are available [13] and numerous articles investigate the earthquakes and the response process being occurred.

Railway systems might suffer extensive damage and it can be even entirely destroyed by an earthquake. The actual damage depends on the local conditions, especially on the distance from the epicenters, the relative position of the railway system elements, the directional effects of the earthquake, and the types as well as the mechanical properties of the soil.

Fig. 1 demonstrates the size of the damage zones (maximum distance from epicenters), which might considerably vary (see the track damages).

The specialists identify bridges as the most critical elements of the railway systems [16]. They also underline that their recovery is a more complex task than the reparation of the tracks. Therefore, preliminary actions should focus on bridges with attention to (i) the enhancement of the rules and regulations to design, construction, and operation, (ii) the development of passive and active monitoring systems including remote condition monitoring, (iii) the augmentation of the preparedness level and (iv) the introduction of the active total management system related to response and recovery management.

\subsection{Disaster management legacy}

The required preparedness level is (i) expected by the economy and society (stakeholders), (ii) estimated by professional experts and (iii) defined by policy and rule makers. The preparedness level should make a balance between the demands of the economy and society as well as the available financial support, between the acceptable risk and willingness to pay for hazard reduction.

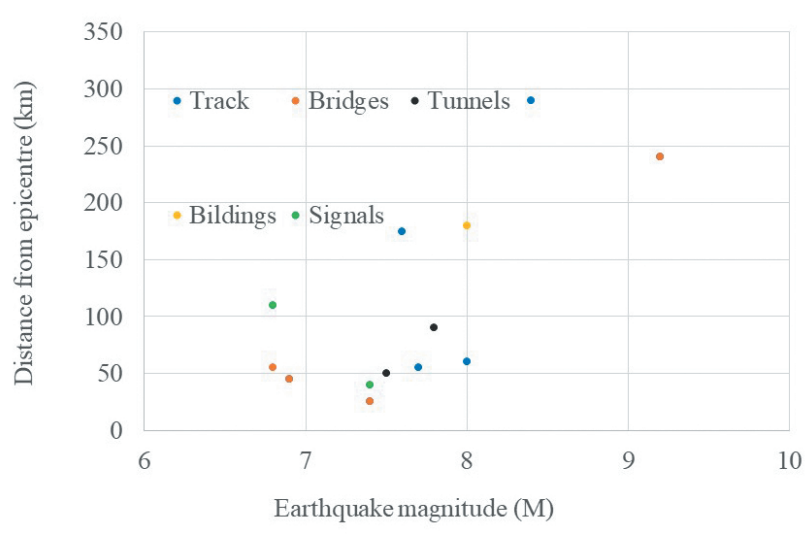

Fig. 1 The maximum distance from the epicenter to the railway facilities being damaged (based on data from $[14,15]$ ) 
The laws, directives, rules, and requirements regulating disaster management were investigated. The top-level emergency management is defined by policy makers [17] and by legislation $[18,19]$.

The comparison of the international regulations [20, 21] shows that the national regulations usually follow the concept described by the CMDA (The Caribbean Disaster Emergency Management Agency) [22]. Further analysis of the emergency management regulations of US, Japanese, European, Hungarian and Kazakhstan's regulatory systems helped to conclude the followings:

- there is no principal difference in the compared regulatory systems, neither structural, nor in the contents,

- there is a lack of regulation related to the use of the railway systems in disaster management.

Each country organizes its central national response framework by creating laws [11, 23, 24]. U.S. may have the largest and most regulated framework [25]. In Europe, the Civil Protection Mechanism [26] regulates the cooperation between the EU Member States and 6 Participating States in the field of civil protection, with a view to improve prevention, preparedness, and response to disasters.

\subsection{Changes in economy and society nobilities}

The changes in economy and society can be characterized by the next five most important factors: (i) rapid industrialization including the establishment of plants producing dangerous products or using dangerous technologies, (ii) globalization (including the shift of dangerous production to third countries), (iii) design and establishment of large systems that considerably change the nature and introduce new safety problems (like water reservoirs), (iv) migration, urbanization causing extra travel and transportation demand and concentrating people in large cities and (v) increase the importance of security defense.

According to the railroad damage, to characterize the new safety and security problems, a semi-empirical approach based on GIS (Geographic Information System) maps $[11,27,28]$ can be used.

\subsection{Technology developments}

Technology developments support disaster management in three major forms:

- development of a new approach (vision) being adapted even to the new factors/trends (like the increasing role of sustainability, climate change, or the use of new supply change lines, as the new Silk Road' freight train from China to Europe),
- new methods, new solutions,

- new technologies.

Disasters management centers based on new technologies may provide a rather accurate actual information on the occurred events, disasters. However, disaster response management also require to predict the future processes, as outcomes of the applied actions and the appeared aftershocks or secondary effects. Presently, the available technology and the collected "historical" information permit to create a new simulation and a short-term prediction model to support the response management in the critical first 8-15 days.

This paper introduces a new approach with the novelty of synthesizing the engineering and management methods and implementing a recursive adaptive simulation. The developed method utilizes a special Markov model that approximates the processes after the main earthquake occurrence, being combined with the new aftershock prediction and time-depending simulation of the secondary effects as tsunami or floods. The simulation also integrates other special models, as the identification of the critical infrastructure, the security checks, and the novel aftershock forecast method. The two core elements of the paper are (i) the definition of the operation value of the critical infrastructure and (ii) the introduction of a novel indicator, as the relative unusable truck length.

As shown in the Fig. 2, new technologies are in the enhancement of monitoring, operation center and decision support systems.

Here passive monitoring means for example that several sensors might be integrated in the critical infrastructure (like bridges, tunnels) or video cameras are installed in the environment. The information can be collected remotely, via internet. Active monitoring can be classified into soft and hard methods. Soft methods deal with sensors activating after the earthquake occurrence, such as sending drones $[11,29]$ to explore and estimate the importance

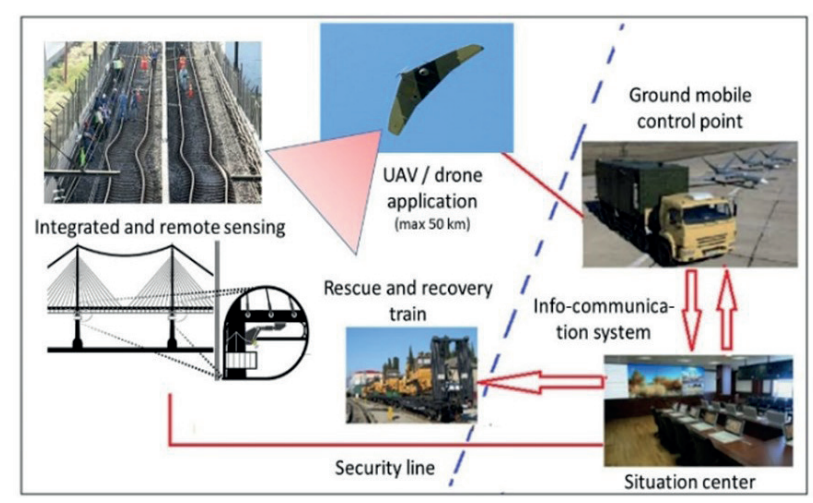

Fig. 2 Using new technologies in disaster response management 
of the caused damage. Hard active monitoring uses sensors and small actuators integrated in the infrastructure to measure signals (like impact or vibration) and record the resulting response. The test might be activated automatically (regularly) and from the distance by command points (for example in case of an earthquake). All data measured can be collected through the internet and operators can evaluate these in operator centers. Situation awareness, evaluation and decision making process is supported by simulation sub-centers.

All the new methods require special approaches and the establishment of dedicated sub-systems.

\section{Improved methods, models}

Improved and new models were developed to support the general model and the defined new approach to sustainability related to critical infrastructure. As examples, four new approaches/models are shortly introduced here.

\subsection{Identification of critical infrastructure}

Numerous articles, reports are dealing with response management, hazard assessment, preparedness, or sustainability of critical infrastructures [30-32]. The authors [11, 33, 34] created the background to harmonize the requirements of sustainability and disaster management. The developed and introduced new approach and methodology of maintaining the sustainability of a critical infrastructure against natural disasters (see text box of Table 1). In short, some examples of the aspects in table are the followings:

- cluster - selection of the cluster of economy or society - as transportation system, or energy supply chain,

- limits - predefinition of the limit -like the investment or capacity,

- damage - estimation of the possible damages (level, process, probability),

- interdependence - definition of the level and cross influences - percent of dependences, - as minimum all the critical infrastructure require energy support, and operated by integrated info-communication systems),

- consequences - the prediction and classification of the consequences.

\subsection{New approach to hazard assessment}

Hazards assessment deals with safety and/or security aspects. Safety accounts for the unwanted event caused by errors, failures radical changes in the environment. It could be well defined by
Table 1 Recommended method for the identification of critical infrastructure

\begin{tabular}{|c|c|}
\hline Cluster & $\begin{array}{c}\text { Chemical industry, food, } \ldots \rightarrow \text { transport } \\
\text { Investment: } \mathrm{x} \rightarrow \mathrm{x}\left(10^{7} \text { EUR }\right) \\
\text { Capacity: } \mathrm{y} \rightarrow \mathrm{y}\left(2 \times 10^{4} \text { people }\right)\end{array}$ \\
\hline Sector & Flood, epidemics, $\ldots \rightarrow$ earthquake \\
\hline Limits & $\begin{array}{l}\text { Limits } \\
\text { (Average score characterising the sector should be } \geq 5 \text { ) }\end{array}$ \\
\hline $\begin{array}{l}\text { Causing } \\
\text { event }\end{array}$ & $\begin{array}{c}\text { Causing event } \rightarrow \text { earthquake }(\mathrm{M}-\text { Magnitude }) \\
(0 \text { for }<6 \mathrm{M}, 1 \rightarrow 6 \mathrm{M}, 3 \rightarrow 7 \mathrm{M}, 6 \rightarrow 8 \mathrm{M}, 10 \text { for } \geq 9 \mathrm{M})\end{array}$ \\
\hline $\begin{array}{l}\text { Destabilizing } \\
\text { factor }\end{array}$ & $\begin{array}{c}\text { Factor (tolerance to the impact caused by earthquakes) } \\
(0 \text { for }<0 \mathrm{M}, \mathrm{Sc} .=\mathrm{M}, \\
\text { (if probability of surveillance } \geq 0,75))\end{array}$ \\
\hline Damage & $\begin{array}{l}\text { Slight - moderate - extensive - complete damage (static, } \\
\text { dynamic damage, collapse, survivability - probability) }\end{array}$ \\
\hline $\begin{array}{l}\text { Interde- } \\
\text { pendence }\end{array}$ & $\begin{array}{c}\text { Level and cross influence of interdependence } \\
\text { (topologic, structural, functional supply } \\
\text { interdependences) }\end{array}$ \\
\hline $\begin{array}{l}\text { Consequ- } \\
\text { ences }\end{array}$ & $\begin{array}{l}\text { Consequences (short, middle and long-term total cost of } \\
\text { losses determined for different level of causing effect) }\end{array}$ \\
\hline $\begin{array}{l}\text { Safety and } \\
\text { Security }\end{array}$ & $\begin{array}{l}\text { Safety and Security } \\
\text { (Risk evaluation methods and method based on } \\
\text { comparative analysis score }=6-(\log \mathrm{R}-6))\end{array}$ \\
\hline Analyses & $\begin{array}{c}\text { Analyses (subjective evaluation of existing and } \\
\text { applicable simulations of damage processes analyses } \\
\text { of possible impartments) }\end{array}$ \\
\hline $\begin{array}{l}\text { Prepared- } \\
\text { ness }\end{array}$ & $\begin{array}{c}\text { Preparedness } \\
\text { (Subjective evaluation of possible improvements) }\end{array}$ \\
\hline
\end{tabular}

- the risk that accounts for the occurred emergency events (related to the working hours),

- the accepted level of safety (generally being equal to a risk occurrence ranging from $10^{-4}$ to $10^{-6}$ per hour),

- the possible implementation of the reliable system from lower reliable elements, and sub-systems used in parallel.

Security is an emergency situation caused by the unlawful and/or intended (terror) actions. It varies according to the form of threats. Security risk levels being accepted (by the society) are highly depending on real threats. For example, the risks of attacking the critical infrastructure by a bomb should be less than $10^{-6}$ per hour (about one event during 115 years), while the risk of a simple cyber attack equals to approximately 20-50 events a year, with serious cyber attacks (resulting to death) less than $10^{-6}$ per hour.

A new and disruptive method of risk estimation was developed. It is based on the evaluation of the different risk factors:

$$
R_{n}=R_{C} \prod_{i=1}^{6} \frac{R F_{n_{i}}}{R F_{C_{i}}},
$$


where $R$ is the security risk, $R F$ a security risk factor, indexes $n, C$, define the new system, new structural or operational solution and conventional, existing system, while $i$ lists the risk factors as assets, vulnerability, outcomes, threat, violence, success.

Table 2 demonstrates the application of the improved security risk estimation concept on the example threat to train bridge in urban region close to city center. The risk estimation is the result of authors' calculation supported by experts.

\subsection{Modelling the seismic aftershock appearance}

The development of response methodology should have models for the possible prediction of aftershock appearances. This requires two tasks: (i) the prediction of aftershocks with the possible size of the impacted area and (ii) the evaluation of the damage extent caused by the earthquakes.

While several models are used for aftershock prediction $[9,10]$, unfortunately all these have at least two weaknesses:

- cannot provide general approximation due to the large uncertainties in their parameters,

- cannot give information on the location of aftershock occurrences.

Theoretical studies concluded that aftershocks occur randomly and in elliptic areas (see Fig. 3(a) showing the distribution of 243 earthquakes being larger than magnitude 5.0 that followed the mainshock (of $M_{w}=9.2$, Alaskan (1964) earthquake) during 10 months [35]), 90\% of which are appeared in drawn ellipsis).

A special model was developed $[11,12]$ using a Monte Carlo Simulation to predict the aftershock occurrences and bivariate normal models to define the local sites of the aftershock appearance (Fig. 3(b)). This method uses 4 random values, 2 for Monte Carlo simulation and 2 for the prediction of the location.

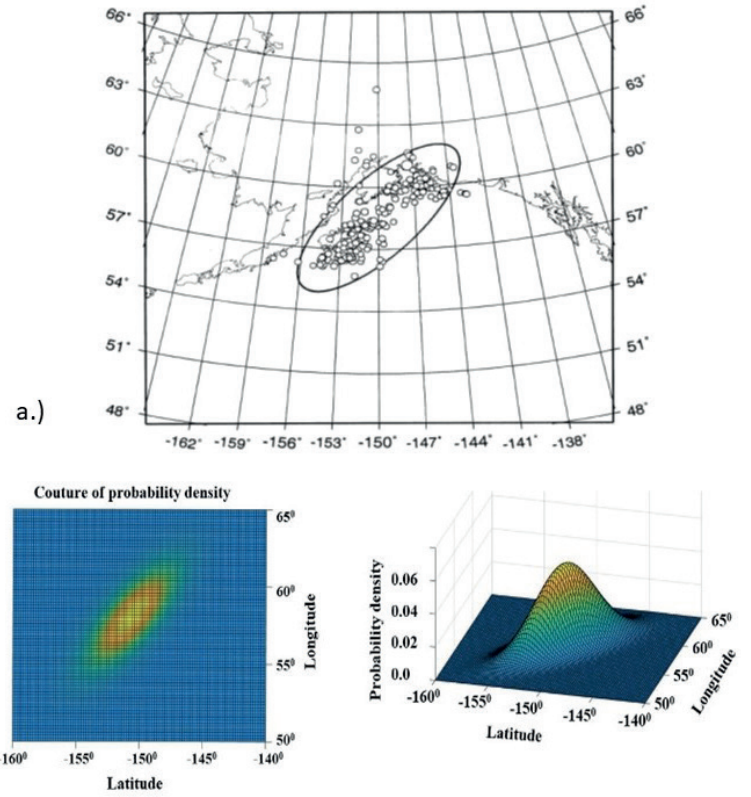

Fig. 3 a) Aftershocks distribution and b) bivariate normal distribution approximating the aftershocks (appeared after Alaskan $M_{w}=9.2$ earthquake)

\section{General model}

Nowadays, the life-cycle and more particularly the total life-cycle cost (TLCC) is recommended to use for the objective evaluation of large natural-ecological-sociotechnogenic systems. The operational objectives (design, building, operation, maintenance, repairing, recycling) of the critical infrastructures are

- serving their primary tasks (e.g., supporting the changes in travel modes at large modal split centers),

- with minimum cost,

- at accepted level of safety.

By applying the TLCC calculation methodology, the following approach can be recommended to evaluate the operation value (OV) of the critical infrastructure:

Table 2 Security risk estimation for city railway bridge

\begin{tabular}{|c|c|c|c|c|c|c|c|c|c|}
\hline \multirow[t]{2}{*}{ No. } & \multirow{2}{*}{$\begin{array}{c}\text { Risk } \\
* 10^{-7} 1 / \mathrm{h}\end{array}$} & \multirow[b]{2}{*}{$\begin{array}{l}\text { initial risk } \\
\left(* 10^{-7} 1 / \mathrm{h}\right)\end{array}$} & \multicolumn{6}{|c|}{ Initial risk } & \multirow{2}{*}{$\begin{array}{c}\text { Risk } \\
* 10^{-7} 1 / \mathrm{h}\end{array}$} \\
\hline & & & asset & $\begin{array}{l}\text { vulner- } \\
\text { ability }\end{array}$ & consequences & threat & violance & "succes" & \\
\hline 1 & in-side attacks & 6.5 & 0.95 & 0.96 & 0.84 & 0.9 & 1.1 & 0.96 & 4.7325 \\
\hline 2 & bomb (in-side) & 4.2 & 0.92 & 0.92 & 0.88 & 0.78 & 1.03 & 0.84 & 2.1111 \\
\hline 3 & attack by large vehicles & 4.7 & 0.82 & 0.88 & 0.76 & 0.82 & 0.97 & 0.92 & 1.8862 \\
\hline 4 & attack by UAVs/drones/UGVs & 8.7 & 1.1 & 0.98 & 0.92 & 0.96 & 1.14 & 1.06 & 10.009 \\
\hline 5 & armed attack & 2.3 & 1 & 1.02 & 1 & 1.08 & 0.98 & 1.12 & 2.781 \\
\hline 6 & biological or chemical attack & 1.4 & 0.9 & 1.05 & 1.04 & 0.97 & 0.84 & 1.24 & 1.3902 \\
\hline \multirow[t]{2}{*}{7} & cyber attack & 12.6 & 1.3 & 1.12 & 1.1 & 1.24 & 1.15 & 1.36 & 39.137 \\
\hline & total & & & & & & & & 62.047 \\
\hline
\end{tabular}


$O V_{c i}=\frac{T L C C_{c i}}{T L C W_{c i}}=O V_{i}+\Delta O V_{i, c i}$,

where $T L C C$ is the total life-cycle cost, $T L C W$ is the total life-cycle work (that in first order can be defined as unit of time), indexes $c i, i$ define the critical infrastructure, (conventional) infrastructure, while $\Delta$ takes into account the difference between the conventional infrastructure and the critical infrastructure. The differences are caused by several aspects, which can be classified in the following three major groups:

- stronger safety requirements as the possible accidents, emergency situations that may cause significant effects on the economy, human life, nature and/or cultural values,

- increased security requirements caused by the same larger dimensions and influences, and

- extra requirements to survive the disasters as earthquakes.

All the differences lead for example to build stronger constructions, to apply duplications, to develop and implement condition monitoring, warning systems, preparedness applying the rules and methods of emergency management, to reduce the disaster aftermaths, or to apply technologies improving the constructions derived from the analysis of the real disasters occurred.

$$
\Delta O V_{i, c i}=\sum_{i=1}^{n} \sum_{j=1}^{m} \sum_{q=1}^{r} w_{i, j, q} \Delta O V_{i, c i_{i, j, q}},
$$

where

$\Delta O V_{i, c i_{i, j, q}}=\frac{\Delta T L C C_{i, c i_{i, j, q}}}{T L C W_{i, c i_{i, j, q}}}, \forall i, j, q$,

where $i=1,2, \ldots, n, j=1,2, \ldots, m ; q=1,2, \ldots, r$ defines the series of aspect (forms) of safety, security and disasters; $w$ are the weighting coefficients; $\Delta O V_{i, c i_{i, j, q}}$ are the differences in operational value of conventional and critical infrastructure (increases in cost) caused by $i, j, q$ types of aspects (improvements in constructions).

\subsection{Chosen governing indicator}

Several indicators can be used to describe the real damages of railway systems caused by earthquakes and its secondary effects. From the stakeholders' point of view, especially from the society and economy point of view, the usability of the railways is one of the most important indicators. In case of disaster and disaster response, the unavailability or unusable might be even more important performance of the partially damaged railway systems. Practically, a rail line might be destroyed in 2-4 times of 4-15 m long segments, which - due to the lack or alternative tracks or deviation options - might even block hundreds of $\mathrm{km}$ of track length.

A new governing indicator was introduced as a relative unusable track length, , which can be represented as

$l_{u t}(t)=\frac{1}{L} \sum_{j=1}^{m} L_{u t_{j}}\left(w_{j}, M, r_{j}, \alpha_{j}, V_{s_{j}}, d_{j}\right)$,

where: $L$ is the total usable length of the railway network (sum of the length of all the network elements that can be operated), $j=1,2, \ldots, m$ are numbers of critical objects in the railway systems (such as railway station, bridges, tunnels) and segments of track between the critical elements, $L_{u t_{j}}$ is the unusable track length caused by the damage of the " $j$ " object, $w_{j}$ - weighting coefficient depending on the structural solutions, lifetime, time since last restoration or maintenance/repair, determining the damage of the given $j$-th object, $M$ - the magnitude of the earthquake, $r_{j}-$ the distance of the given object from the center of the earthquake, $\alpha_{j}$ - the angle between rupture propagation and mean axis of the object, $V_{s_{j}}$ - shear wave velocity that is a soil measurable mechanical property, and $d_{j}-$ is a statistical damage coefficient.

This indicator may vary from zero, up to 1 (100\%). All the disaster events (e.g., earthquake, aftershock, secondary effects as tsunami, floods) are increasing, while the applied response (should) are decreasing the value of the indicator. The state space of the indicator can be divided $n$ sub spaces and thus the indicator can be approximated as

$l_{u t}(t)=\sum_{i=1}^{n} P_{i}(t) l_{u t_{i}}$,

where $P_{i}$ is the probability, showing that the relative unusable track length parameter, $l_{u t}$ at time $t$ is in the $i$-th subspace, and $l_{u t_{j}}=\left(l_{u t_{j}}-l_{u t_{j-1}}\right) / 2$ for $i=1,2, \ldots n$.

As known, such models (like Eq. (6)) might be approximated by a Markov chain (as it described in more detailed in $[11,12]$.

\subsection{Developed methodology}

A special methodology was introduced and developed, which synthetized the engineering and management methods for response management related to earthquake damaged railway system [11]. This approach recommends to use direct (immediately on site) response, in order to (i) save lives and goods and (ii) minimize the losses. 
The methodology is based on the actual priority list of critical infrastructure elements, following their restoration and simulated results of chosen actions (repair of the selected critical elements). Simulation is composed of numerous simulation cycles, being based on Markov chain approximation of the model Eq. (6). It is recommended to define the priority list and repeat the simulation each 0.1 hours with "fresh" or adjusted parameters (transition matrix) and revised priority rules.

The simulation process (Fig. 4) includes the following elements:

- Preparedness: long-term, large research on risk analysis, planning the monitoring system, establishing the response center, staff recruiting, owning the simulation techniques, building the depots of materials, machines required for the restoration.

- Response initiation: immediately after suddenly occurred earthquake, identification of the size of damage, definition of the priority rules, initiation of the simulation support and first actions.

- First level response: evaluation of the events, identification of the damages estimation of the major indicator (relative unusable truck length), identification of the elements, (parameters) of the approximation model, determining the (predictable) response process, definition of the revised priority list of the required and recommended actions.

- Second level of response: that is a further and broader evaluation being applied once considerably new information is received (e.g., from the integrated monitoring system, extra measurements provided by mobile measuring centers, remote sensing, or drones), or serious aftershocks, secondary effects are expected (initiated by simulation results or changes in the prioritization), appeared. This step covers (i) the collection and summary of new data, (ii) the comparison of the previous simulation results with the available new records, (iii) the identification of new (like aftershocks) and secondary (as floods, tsunamis) events and (iv) the execution of extensive simulations.

- Third level of response: regular evaluation of how objectives were reached, and how the system returned to its standard operational level. It also initiates the next step recovery planning, by evaluating of the indicators being specially developed for this purpose.

- Long Term Recovery Planning: preparing the future long term recovery process including (i) the evaluation and the characterization of the "final" damages of the critical elements (damages the require long-term reparation or the construction of new elements), (ii) the definition of the objective of the long-term recovery process, and (iii) the preliminary design of the long-term recovery process including the technical and financial aspects.

\section{Case study - concept verification}

The recommended recovery management (Fig. 4) requires preliminary studies, good infrastructure, and technical staff (to perform measurements, simulation studies and result assessment), in order to make the appropriate decisions. The leaders of this management process must have an outstanding theoretical and practical knowledge as well as an extensive experience (implied knowledge) to successfully and efficiently use the recommended methodology.

The described concept was tested with a simple and presumed event case, by being applied to a simplified railway system similar to Kazakhstan's southern railway network, with 1 tunnel and 338 bridges from a total of 1720 railway bridges in the state (Fig. 4). This part of Kazakh railway system is endangered at the western part by floods, at the eastern part by earthquakes [4, 36] from south of Almaty by mudflow (glacial lake outburst flood) [37], while from north of Almaty by flood and industrial hazards [11].

The required inputs including the records on earthquakes and especially on railway damages were collected by the first author of this paper, in his $\mathrm{PhD}$ thesis [11].

This study - as a case study - deals with a limited scenario, seeing that some secondary effects like tsunami cannot be considered. While, Tsunami propagation might be the most predictable event $[2,5]$ that is extensively studied and verified, the case study demonstrates the general applicability of the developed simulation model based disaster response management.

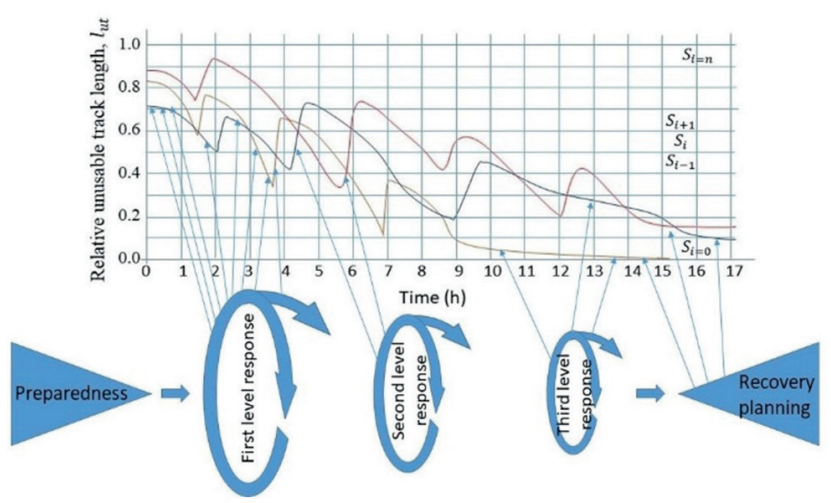

Fig. 4 Concept of the developed response management system related to large technical systems damaged by serious disaster events, such as earthquakes [11] (upper figure: changes in major indicators, lower figure: simulation methodology) 
Fig. 5 demonstrates the typical simulation results supporting the response management. Here, state space (of the probability of staying in the given sub-space) was divided into 20 subspaces (with 0.05 range) and the two extreme values (zero and one) were also added as subspaces. During the simulation, the chosen time interval (as cycle step) was 6 minutes $(0.1 \mathrm{~h})$.

Figs. 5(a) and (b) demonstrate the results, when a constant transition matrix and after event effects were used. In this simulation, the time interval (as cycle step) was $0,1 \mathrm{~h}$. Occurrences of the aftershocks were simulated using a Monte Carlo method, described above. The secondary effects were evaluated by the available statistical data and models as well as the records provided by the information and observation sub-systems.

Generally, the first simulation cycle, as first level response (Fig. 4.) might be repeated at each time-cycle, while the further cycles (second and third level responses) should be applied in case of necessity.

The aftershocks and secondary effects such as flood, appear in the Fig. 5(a) and (b) as sudden changes.

\section{Conclusions}

This paper introduced a new disaster response methodology, which is recommended to be implemented as an active adaptive response to earthquake damage at large ecological-socio-technogenic systems playing a deterministic role in the economy and society. A special indicator was introduced, defining the relative unusable track length of the system, as a governing indicator in the response management. The recommended concept was tested on a railway system.

The applicability of the recommended methodology depends on the available sources, methods, simulation techniques, software, which must be preliminarily tested and adapted to the given region (e.g., by using GIS data).

Instead of a simple, but adapted Markov model, more complex models can be developed and applied.

Several special sub-models must be developed and applied before the use of the recommended response management concept. For example, a Monte Carlo simulation was used to model the aftershocks; or the improved methods were studied to estimate the fragility curves [38-40] of the possible damages of the given critical infrastructures caused by the earthquakes.

The results of the case study (with simulation techniques) demonstrated that the developed methodology can support the response management related to earthquake
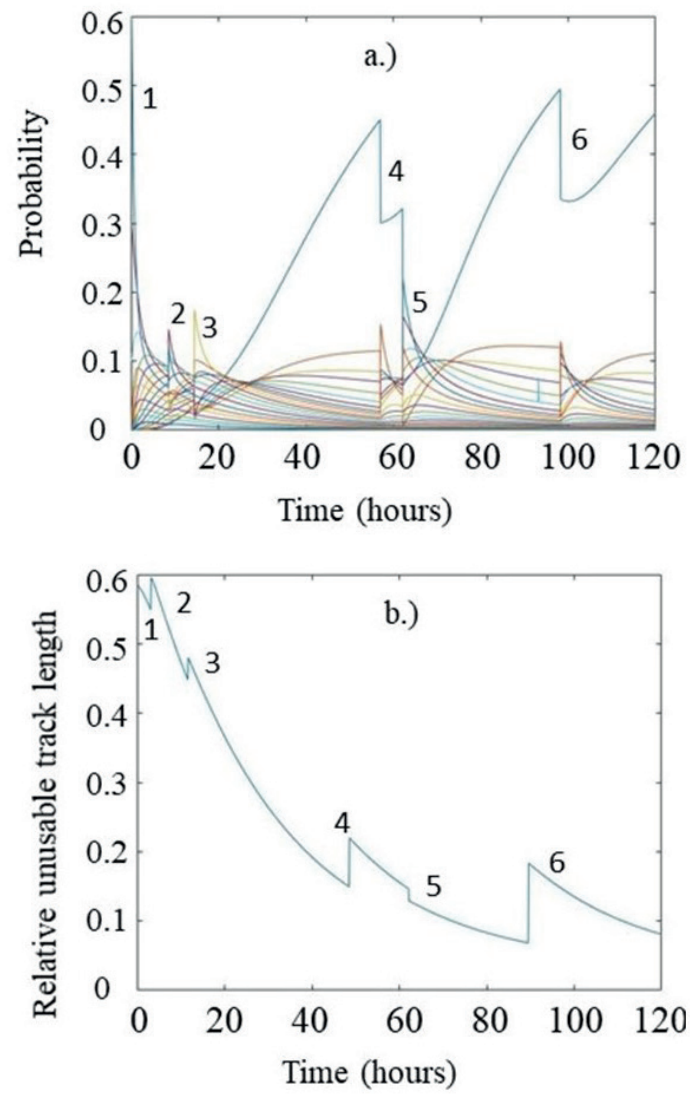

Fig. 5 Case study results based on the described methodology and sub-models: $\mathrm{a}, \mathrm{b}$ - simulation with constant transition matrix and after event effects: 1. - earthquake caused the effect, 2.- correction after measurements (by UAV or other tools), 3.- aftershock, 4.- flood, 5.system indicator updates due to updated information on flood and real damage caused, 6.- aftershock

damaged railways that can be applied to reduce the required time to recover and assist the effective use of the available resources. The objective of rapid recovery is to return the railroad and the railway system to the operational level. Therefore, this part of the recovery can be finished in 2-3 days. In case of a long-term secondary effect, for example, a destroyed river dam, the quick recovery time might increase to 6-10 days. The complete recovery of the railroad and railway system might require up to 1-3 years.

The studies show that

- the disasters response management of the large ecological-socio-technogenic systems might be supported by the introduced simulation model based methodology,

- the role of the railway systems in (earthquake) response management might be considerably improved,

- the developed methodology may significantly reduce the required time to restore the railway system. 


\section{References}

[1] Teplykh, S. Y., Strelkov, A. K. "Characteristics of Railroad Naturaltechnogenic Complexes", Procedia Engineering, 111, pp. 742-747, 2015.

https://doi.org/10.1016/j.proeng.2015.07.140

[2] Oishi, Y., Piggot, M. D., Maeda, T., Kramer, S. C., Collins, G. S., Tsushima, H., Furumura, T. "Three $\square$ dimensional tsunami propagation simulations using an unstructured mesh finite element model", Journal of Geophysical Research: Solid Earth, 118(6), pp. 29983018, 2013.

https://doi.org/10.1002/jgrb.50225

[3] Kia, M. B., Pirasteh, S., Pradhan, B., Mahmud, A. R., Sulaiman, W. N. A., Moradi, A. "An artificial neural network model for flood simulation using GIS: Johor River Basin, Malaysia", Environmental Earth Science, 67, pp. 251-264, 2012.

https://oi.org/10.1007/s12665-011-1504-z

[4] Silacheva, N. V., Kulbayeva, U. K., Kravchenko, N. A. "Probabilistic seismic hazard assessment of Kazakhstan and Almaty city in peak ground accelerations", Geodesy and Geodynamics, 9(2), pp. 131141, 2018.

https://doi.org/10.1016/j.geog.2017.11.002

[5] Bagiya, M. S., Kherani, E. A., Sunil, P. S., Sunil, A. S., Sunda, S., Ramesh, D. S. "Origin of the ahead of tsunami traveling ionospheric disturbances during Sumatra tsunami and offshore forecasting", Journal of Geophysical Research: Space Physics, 122(7), pp. 7742$7749,2017$.

https://doi.org/10.1002/2017JA023971

[6] Bán, Z., Győri, E., Tóth, L., Gráczer, Z., Mahler, A. "Characterization and Liquefaction Hazard Assessment of Two Hungarian Liquefied Sites from the 1956 Dunaharaszti Earthquake", Periodica Polytechnica Civil Engineering, 63(3), pp. 713-721, 2020. https://doi.org/10.3311/PPci.15607

[7] Helmstetter, A., Kagan, Y. Y., Jackson, D. D. "Comparison of Short-Term and Time-Independent Earthquake Forecast Models for Southern California", Bulletin of the Seismological Society of America, 96(1), pp. 90-106, 2006.

https://doi.org/10.1785/0120050067

[8] Edwards, F. L., Goodrich, D. C., Hellweg, M., Strauss, J. A., Eskijian, M., Jaradat, O. "Great East Japan Earthquake, JR East Mitigation Successes, and Lessons for California High-Speed Rail", Mineta Transportation Institute, San José State University, San José, CA, USA, Rep. 12-37, 2015.

[9] Reasenberg, P. A., Jones, L. M. "Earthquake Hazard After a Mainshock in California", Science, 243, pp. 1173-1176, 1989. https://doi.org/10.1126/science.243.4895.1173

[10] Page, M. T., van der Elst, N., Hardebeck, J. L., Felzer, K., Michael, A. J. "Three Ingredients for Improved Global Aftershock Forecasts: Tectonic Region, Time-Dependent Catalog Incompleteness and Intersequence Variability", Bulletin of the Seismological Society of America, 106(5), pp. 2290-2301, 2016. https://doi.org/10.1785/0120160073

[11] Kinzhikeyev, S. "Modelling and management for supporting the recovery of railway systems after earthquakes", $\mathrm{PhD}$ Thesis, Budapest University of Technology and Economics, 2020.
[12] Kinzhikeyev, S., Rohács, J., Rohács, D., Boros, A. "Sustainable Disaster Response Management Related to Large Technical Systems", Sustainability, 12(24), Article number: 10290, 2020. https://doi.org/10.3390/su122410290

[13] EPOS "SeismicPortal", 2020. [online] Available at: https://www. seismicportal.eu/ [Accessed: 12 November 2020]

[14] Byers, W. G. "Railroad lifeline damage in earthquakes", presented at 13th World Congress on Earthquake Engineering, Vancouver, Canada, Aug. 1-6, 2004.

[15] Sekerbekov, U. T. "Разрушение транспортных сооружений при сильных землятресениях прошлого с 1895-1988 годы" (Damage of transport infrastructure caused by strong earthquakes occurred between years 1895-1988), The Bulletins of M. Tynyshbayev Kazakh Academy of Transport \& Communication, vol. 62(1), pp. 71-77, 2010

[16] Misra, S., Padgett, J. E. "Towards Resilience Modelling of Railway Networks - A Case Study on Shelby County, Tennessee", In: Safety, Reliability, Risk, Resilience and Sustainability of Structures and Infrastructure, 12th International Conference on Structural Safety and Reliability, Vienna, Austria, 2017, pp. 2987-2996.

[17] Sylves, R. T. "Disaster Policy and Politics: Emergency Management and Homeland Security", 3rd ed., CQ Press, Washington, DC, USA, 2019.

[18] AREMA "Seismic design for railway structures, Chapter 9", In: Manual for Railway Engineering, American Railway Engineering and Maintenance-of-Way Association, Lanham, MD, USA, 2018.

[19] Benahmed, B., Hamoutenne, M. "Use of the Artificial Neural Networks to Estimate the DRF for Eurocode 8", Periodica Polytechnica Civil Engineering, 62(2), pp. 470-479, 2018. https://doi.org/10.3311/PPci.8139

[20] IFRC \& UNDP "Effective law and regulation for disaster risk reduction: a multi-country report" IFRC \& UNDP, International Federation of Red Cross and Red crescent Societies - United Nations Development Programme, New York, NY, USA, 2014.

[21] IFRC \& UNDP "The Handbook on Law and Disaster Risk Reduction", International Federation of Red Cross and Red Crescent Societies and United Nations Development Programme, Geneva, Switzerland, 2015.

[22] CDEMA "Model Comprehensive Disaster Management Legislation and regulations 2013", CMDA - The Caribbean Disaster Emergency Management Agency, St. Michael, Barbados, 2013.

[23] Tóth, R. "A Magyar Polgári Védelem fejlesztésének szükségessége, lehetséges iránya, a NATO tagság, a Magyar Honvédség korszerüsítése és a hazai katasztrófavédelmi rendszer helyzetének tükrében" (Necessity and possible direction of development of the Hungarian Civil Defense in the light of NATO membership, the modernization of the Hungarian Armed Forces and the situation of the domestic disaster protection system), PhD Thesis, Hungarian Defense University, 2000.

[24] Boros, A., Robotka, I. "A 21. Századi önálló magyar közigazgatási bíróság felállításának kihívásai" (Challenges of the Establishment of 21st Century Autonomous Administrative Courts), Pro Publico Bono - Public Administration, 4(7), pp. 22-45, 2019. https://doi.org/10.32575/ppb.2019.4.2 
[25] FEMA "Federal Emergency Management Agency" 2020. [online] Available at: https://www.fema.gov/ [Accessed 14 January 2020]

[26] EU "Decision No 1313/2013/EU of the European Parliament and of the Council of 17 December 2013 on a Union Civil Protection Mechanism", Official Journal of the European Union, L 347/924, 2013.

[27] ESRI "GIS best practice, GIS for Earthquakes", Environmental Systems Research Institute, New York, NY, USA, 2007.

[28] Rusydy, I., Faustino-Eslava, D. V., Muksin, U., Gallardo-Zafra, R., Aguirre, J. J. C., Bantayan, N. C., Alam, L., Dakey, S. "A GIS-Based Earthquake Damage Prediction in Different Earthquake Models: A Case Study at the University of the Philippines Los Baños, Philippines", Philippine Journal of Science, 147(2), pp. 301-316, 2018.

[29] Restás, Á., Zhaulybayev, A., Shumatov, E., Akshulakov, K. "Disaster responders' activities supported by drone application", presented at Workshop on Earthquake Response Management, Kokshetau, Kazakhstan - Budapest, Hungary, Aug. 24, 2020.

[30] Moteff, J. "Risk Management and Critical Infrastructure Protection: Assessing, Integrating, and Managing Threats, Vulnerabilities, and Consequences", Congressional Research Service, The Library of Congress, Washington, DC, USA, 2005.

[31] Alcaraz, C., Zeadally, S. "Critical infrastructure protection: Requirements and challenges for the 21 st century", International Journal of Critical Infrastructure Protection, 8, pp. 53-66, 2015. https://doi.org/10.1016/j.ijcip.2014.12.002

[32] Guidotti, R., Chmielewski, H., Unnikrishnan, V., Gardoni, P., McAllister, T., van de Lindt, J. "Modelling the resilience of critical infrastructure: the role of network dependencies", Sustain Resilient Infrastructure, 1(3-4), pp. 153-168, 2016. https://doi.org/10.1080/23789689.2016.1254999

[33] Rohács, D., Rohács, J. "Identification, evaluation and management with critical infrastructure of the transportation systems", Rea-Tech Engineering Ltd., Diósd, Hungary, 2014.
[34] Kinzhikeyev, K., Turembayeva, A., Arifyanov, S. B., Rohács, J., Shariphanov, S. D., Boros, A. "Sustainability of critical infrastructure against to the natural disaster (earthquake)", presented at Workshop on Earthquake Response Management, Kokshetau, Kazakhstan - Budapest, Hungary, Aug. 24, 2020.

[35] Christophersen, A., Smith, E. G. C. "A global model for aftershock behaviour", In: Proceedings of the 12th World Conference on Earthquake Engineering, Auckland, New Zealand, Article number: 0379, 2000.

[36] Grützner, C., Walker, R. T., Abdrakhmatov, K. E., Mukambaev, A., Elliott, A. J., Elliott, J. R. "Active Tectonics Around Almaty and along the Zailisky Alatau Rangefront", AGU Advencing Aerth and Space Science, 36(10), pp. 2192-2226, 2017. https://doi.org/10.1002/2017TC004657

[37] Blagovechshenskiy, V., Kapitsa, V., Kasatkin, N. "Danger of GLOFs in the Mountain Areas of Kazakhstan", Journal of Earth Science and Engineering, 5, pp. 182-187, 2015. https://doi.org/10.17265/2159-581X/2015.03.003

[38] Despotaki, V., Burton, H. V., Schneider, J., Burton, C. G. "'Back to Normal": Earthquake Recovery Modelling", Global Earthquake Model Foundation (GEM), Sacramento, CA, USA, Rep. 2017 V1.0.0, 2017.

[39] Nagethi-A, F., Shashavar, V. L. "Development of fragility and reliability curves for seismic evaluation of a major prestressed concrete bridge", presented at 13th World Conference on Earthquake Engineering, Vancouver, Canada, Aug. 1-6, 2004.

[40] Hübner, B., Mahler, A. "Analysis of Seismic Fragility Functions of Highway Embankments", Periodica Polytechnica Civil Engineering, 64(4), pp. 1162-1169, 2020. https://doi.org/10.3311/PPci.16483 